\title{
Cash Waqf Linked Social Entrepreneur
}

\author{
Novi Febriyanti \\ UIN Sunan Ampel Surabaya \\ Email:novikfbr@gmail.com
}

\author{
A. Fikri Amiruddin Ihsani \\ UIN Sunan Ampel Surabaya \\ Email: fikriamiruddin27@gmail.com
}

\begin{abstract}
Al-Khaibar minimarket's one of development results of cash waqf linked social entrepreneur from productive waqf management inpatient rooms of the Very Important Person (VIP) class at Hospital of UNISMA Malang. The purpose of this study was to determine management and development of productive waqf through Al-Khaibar minimarket business at the UNISMA foundation and distribution of benefits at productive waqf management through Al-Khaibar minimarket business at the UNISMA foundation. The research method used descriptive qualitative using a sociological and empirical approach. Researcher took object of research at State Islamic University of Malang (UNISMA) related to management of cash waqf linked social entrepreneurs. The results of this study prove that productive waqf management used in accordance with George $\mathrm{R}$ Terry's theory namely planning, organizing, actuating and controlling. While distribution of benefits at productive waqf management is from net profits, $20 \%-30 \%$ is distributed to mauquf 'alaih, 10\% for nadzir in accordance with Law of Waqf No. 41 of 2004 paragraph 12 and 60\%-70\% for development of waqf.
\end{abstract}

Key Words: productive waqf; social entrepreneur; minimarket.

\begin{abstract}
Abstrak: Minimarket Al-Khaibar adalah salah satu hasil pengembangan cash waqf linked social entrepreneur dari ruang rawat inap kelas VIP di Rumah Sakit UNISMA Malang. Tujuan dari penelitian ini adalah untuk menentukan manajemen pengelolaan dan pengembangan wakaf produktif melalui bisnis minimarket Al-Khaibar di Yayasan UNISMA serta distribusi hasil manfaat wakaf produktif melalui bisnis minimarket Al-Khaibar di Yayasan UNISMA. Metode penelitian menggunakan deskriptif kualitatif dengan pendekatan sosiologis dan empiris. Peneliti mengambil objek penelitian di Universitas Islam Malang (UNISMA) terkait cash waqf linked social entrepreneur. Hasil penelitian membuktikan bahwa manajemen pengelolaan wakaf produktif yang digunakan sesuai dengan teori George $\mathrm{R}$ Terry yaitu planning, organizing, actuating dan controlling. Sementara distribusi hasil manfaat wakaf produktif adalah dari laba bersih, 20\%-30\%


didistribusikan ke mauquf 'alaih, 10\% untuk nadzir yang sesuai dengan UU Wakaf No. 41 Tahun 2004 Pasal 12 dan 60\%-70\% untuk pengembangan wakaf.

Kata Kunci: wakaf produktif; kewirausahaan sosial; minimarket.

\section{PENDAHULUAN}

Pada Tahun 2019, Garis Kemiskinan Kota Malang berada pada level Rp. 543.966,- per kapita per bulan atau meningkat sekitar 36,8 ribu rupiah dibanding Garis Kemiskinan pada Tahun 2018. Penduduk dengan pengeluaran per kapita per bulan di bawah garis kemiskinan dikatakan sebagai penduduk miskin. ${ }^{1}$ Dengan mengalami peningkatan kemiskinan dari tahun sebelumnya, maka kemiskinan tersebut dapat diatasi dengan beberapa cara alternative yaitu zakat, infaq, shadaqah dan salah satunya adalah wakaf. Hal tersebut sebagai bentuk $h$ \{ablum minannās dengan menaruh rasa perhatian kepada orang sekitar dengan memberikan uluran bantuan bagi yang membutuhkan. ${ }^{2}$ Wakaf disamping sebagai salah satu aspek ajaran Islam yang berdimensi spiritual, juga merupakan ajaran yang menekankan pentingnya mewujudkan kemaslahatan sosial, baik untuk masyarakat terbatas (dzurri) maupun masyarakat luas (khairi) yang berkesinambungan. 3

Wakaf adalah salah satu sarana distribusi kekayaan dalam ajaran Islam. Wakaf memiliki keunikan tersendiri dalam distribusi kekayaan yang tidak dimiliki oleh distribusi lainnya. Wakaf merupakan instrument yang sangat potensial untuk mengentaskan kemiskinan, meningkatkan kesejahteraan masyarakat dan mewujudkan keadilan sosial. ${ }^{4}$ Peran utama dalam pengelolaan wakaf terletak pada nadzir wakaf baik dalam bentuk perseorangan maupun lembaga. Pengelolaan wakaf secara produktif di Indonesia sudah didukung oleh Pemerintah dengan dikeluarkannya Undang-Undang No. 41 Tahun 2004 melalui Lembaga Keuangan Syariah Penyedia Wakaf Uang (LKSPWU). Meskipun payung hokum mengenai pengelolaan wakaf secara produktif telah ditetapkan oleh Pemerintah, namun beberapa lembaga wakaf masih mengelola wakaf secara tradisional.

Seiring berjalannya waktu, wakaf sendiri dapat dikelola tidak hanya melalui pendekatan kesejahteraan sosial dan ibadah akan tetapi dengan pendekatan bisnis. Melalui bisnis, wakaf dapat menjadi produktif dan menghasilkan keuntungan yang kemudian akan digunakan sebagai

\footnotetext{
1 Badan Pusat Statistik Kota Malang, Profil Kemiskinan di Kota Malang Tahun 2019, https://malangkota.bps.go.id/pressrelease/2020/o1/o2/212/profil-kemiskinan-kota-malang-maret-2019.html, diakses pada 28 Desember 2019.

${ }^{2}$ Muhammad Dandy Alif Wildana, Asfi Manzilati, Ḥablum minallāh dan Ḥablum minannās dari Zakah, Jurnal Ilmiah Mahasiswa FEB Universitas Brawijaya, Vol. 2 No. 2, (2013), 47.

3 Mukhlisin Muzarie, Hukum Perwakafan dan Implikasinya Terhadap kesejahteraan Masyarakat (Impelementasi Wakaf di Pondok Modern Darussalam Gontor), (Jakarta: Kementerian Agama RI, 2010), 1.

4 Munzir Kahf, Al-Waqf Al-Islāmy: Tatawwuruhu, Idāratuhu, Wa Tanmiyyatuhu, (Beirūt: Dār al Fikr, 2005), 31.
} 
kemaslahatan sosial dengan pengentasan kemiskinan.5 Menyikapi banyaknya kemiskinan yang membutuhkan uluran bantuan, tentu harus ada upaya untuk bisa mengurangi jumlah penduduk miskin. Salah satu upaya yang dapat mengurangi permasalahan kemiskinan yang ada adalah dengan kombinasi pada wakaf produktif berupa uang tunai pada social entrepreneurs atau kewirausahaan sosial dalam bentuk bisnis. Implementasi tersebut bisa disebut dengan cash wakaf linked social entrepreneurs.

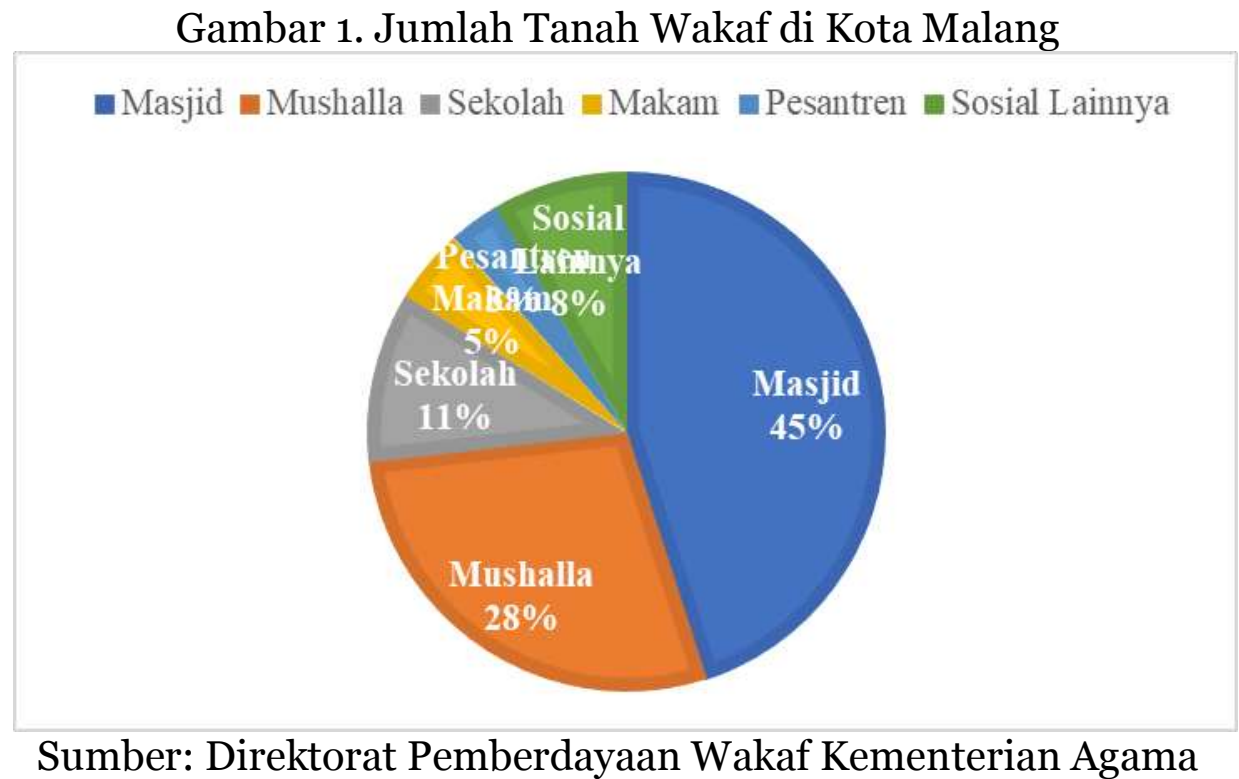

Social entrepreneurs atau kewirausahaan sosial adalah pemanfaatan perilaku kewirausahaan yang lebih berorientasi pada pencapaian tujuan sosial yang tidak hanya mengutamakan perolehan laba, atau laba yang diperoleh dimanfaatkan untuk kepentingan sosial yang berdampak pada minimalisir permasalahan kemiskinan yang sedang terjadi. Social entrepreneurs dapat dijadikan sebagai solusi dalam menghadapi permasalahan kemiskinan yang ada. Social entrepreneurs menawarkan keadilan sosial diantara sesama dengan saling membantu dan mengasihi orang-orang yang sedang mengalami kesulitan. 6

Dengan mengemban misi sosial, social entrepreneur menjadi sebuah model bisnis kewirausahaan yang tidak hanya mementingkan profit semata. Hal ini selaras dengan salah satu ajaran Islam yaitu untuk tolong menolong dan melindungi kaum yang lemah.7 Sebagaimana firman Allah SWT dalam surat AtTaubah ayat 71,8

5 Suhrawardi K. Lubis, Wakaf \& Pemberdayaan Umat, (Jakarta: Sinar Grafika, 2010), 159.

${ }^{6}$ Muhammad Isnan Nurfaqih dan Rizqi Anfanni Fahmi, Social Entrepreneur (Kewirausahaan Sosial) dalam Perspektif Ekonomi Islam, Working Paper Keuangan Publik Islam, No. 8, Seri 1, (2018), 3 .

7 Muhammad Syarif Chaudhry, Sistem Ekonomi Islam: Prinsip Dasar, (Jakarta: Kencana, 2016), 292.

8 Departemen Agama RI, Al-Quran Special for Muslimah, (Jakarta: Cordoba, 2016), 198. 


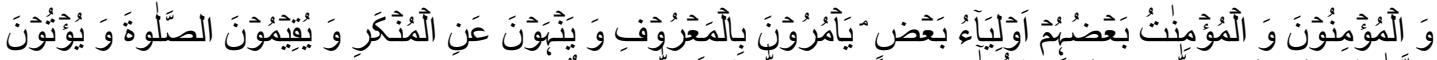

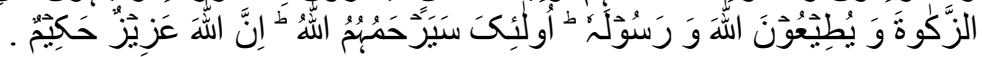

"Dan orang-orang yang beriman, laki-laki dan perempuan, sebagaian mereka menjadi penolong bagi sebagian yang lain. Mereka menyuruh (berbuat) yang makruf dan mencegah dari yang mungkar, melaksanakan shalat, menunaikan zakat dan taat kepada Allah SWT dan Rasul-Nya. Mereka akan diberi rahmat oleh Allah SWT. Sungguh, Allah SWT Maha Perkasa, Maha Bijaksana."

Perkembangan wakaf produktif di Indonesia berjalan menuju arah yang positif. Banyak sekali pesantren, masjid ataupun badan ZISWAF yang mulai mengembangkan wakaf produktif. Bentuk dari wakaf produktif sangatlah beragam, salah satunya penggagas cash wakaf linked social entrepreneur di Malang adalah Yayasan Universitas Islam Malang (UNISMA). Seperti yang dilakukan oleh nadzir wakaf di Yayasan UNISMA, mereka mengembangkan wakaf produktif pada beberapai unit usaha yaitu Ruang Rawat Inap kelas Very Important Person (VIP) di Rumah Sakit UNISMA Malang serta Minimarket AlKhaibar di Jalan Tata Surya Malang.

Pemilihan untuk mengembangkan wakaf produktif melalui bisnis minimarket mendapat respon positif dari masyarakat dikarenakan minimarket ini tidak sekedar menyediakan kebutuhan masyarakat dengan harga terjangkau dan membuka lapangan pekerjaan, namun juga karena perannya dalam kegiatan sosial yang berdampak pada pengentasan kemiskinan masyarakat sekitar. Terkait berbagai definisi diatas bahwa kesuksesan wakaf produktif melalui bisnis minimarket oleh Yayasan UNISMA tidak terlepas dari manajemen pengelolaan dan pengembangannya.

Dengan begitu, penulis tertarik untuk melakukan penelitian yang lebih komprehensif mengenai cash wakaf linked social entrepreneur di Kota Malang dengan rumusan masalah dan tujuan penelitian untuk mengetahui bagaimana manajemen pengelolaan dan pengembangan wakaf produktif melalui bisnis minimarket di Yayasan UNISMA serta bagaimana distribusi manfaat hasil pengelolaan wakaf produktif melalui bisnis minimarket di Yayasan UNISMA.

\section{METODE PENELITIAN}

Metode penelitian ini menggunakan deskriptif kualitatif dengan pendekatan sosiologis dan empiris. Pengertian penelitian empiris sendiri yaitu mengungkapkan implementasi hukum yang hidup dalam masyarakat melalui kegiatan sosial yang dilakukan oleh masyarakat dengan melihat sesuatu kenyataan hukum di dalam masyarakat.9 Dalam penelitian ini penulis menitikberatkan pada hasil-hasil pengumpulan data yang didapatkan secara

\footnotetext{
9 Bambang Soenggono, Metodologi Penelitian Hukum, (Jakarta: PT RajaGrafindo Persada, 1997), 86.
} 
langsung dari para informan maupun narasumber yang telah ditentukan. ${ }^{10}$ Penelitian dilakukan dengan terjun langsung ke lapangan untuk melihat gejalagejala dan peristiwa-peristiwa yang terjadi juga berkaitan dengan manajemen pengelolaan dan pengembangan serta distribusi manfaat hasil wakaf produktif di Yayasan UNISMA. Sedang analisis data bersifat deskriptif, karena penelitian ini menggambarkan dan menguraikan secara objektif hal-hal yang berkaitan dengan cas waqf linked social entrepreneur di Yayasan UNISMA.

\section{WAKAF PRODUKTIF}

Secara bahasa, kata wakaf berasal dari bahasa Arab waqafa yang berarti menahan, berhenti atau diam di tempat atau berdiri. Sedangkan secara istilah, kata wakaf pada awal Islam dikenal dengan nama habs dan shadaqah mempunyai rumusan yang berbeda-beda sesuai pandangan masing-masing ahli fiqh. Pada prinsip menurut para ulama, wakaf adalah amal kebajikan (tabarru'at) yang bersifat lestari, menyediakan suatu harta benda yang dipergunakan hasilnya untuk kemaslahan umat. ${ }^{11}$

Terdapat ayat Al-Quran sebagai dasar hukum adanya praktik wakaf dalam surat Al-Hajj ayat $77,{ }^{12}$

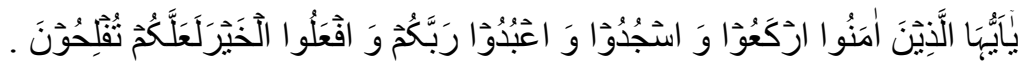

"Wahai orang-orang yang beriman! Rukuklah, sujudlah, dan sembahlah Tuhanmu; dan berbuatlah kebaikan agar kamu beruntung."

Ayat tersebut mengandung perintah secara umum agar kaum muslim dapat menjalin hubungan baik dengan Allah SWT melalui kegiatan ritual yang telah ditetapkan dengan ruku, sujud dan ibadah lainnya melalui kegiatan sosial seperti menjalin hubungan baik dengan sesama, tolong-menolong, santun dan sebagainya. Perintah untuk berbuat kebaikan mengandung petunjuk umum, termasuk didalamnya melaksanakan amalan wakaf, mengingat wakaf merupakan implementasi hubungan baik dengan Allah SWT dan berimplikasi terwujudnya kesejahteraan masyarakat yang dapat mmenjamin hubungan baik antara sesame manusia. ${ }^{13}$

Lalu ada pula hadis yang menggambarkan dianjurkannya ibadah wakaf adalah sebagai berikut, 14

"Diriwayatkan dari Ibn Umar r.a bahwa Umar bin al-Khattab r.a memperoleh tanah (kebun) di Khaibar, lalu ia datang kepada Nabi saw untuk meminta petunjuk mengenai tanah itu. Ia berkata, "Wahai Rasulullah, saya

\footnotetext{
1o Sugiyono, Metode Penelitian Kuantitatif, Kualitatif dan R\&D, (Bandung: Alfabeta, 2019), 293.

${ }^{11}$ Sudirman, Total Quality Management TQM untuk Wakaf, (Malang: UIN Maliki Press, 2013), 50 .

12 Departemen Agama RI, Al-Quran Special for Muslimah, (Jakarta: Cordoba, 2016), 341.

13 Muhammad Abid Abdullah, Hukum Wakaf, (Jakarta: Dompet Dhuafa Republika, 2004), 247.

14 Imam Abi al Husain Muslim bin al-Hujjaj bin Muslim, Al-Jami’ al-Shahih al-Mushamma

Shahih Muslim, Juz 3, (Semarang: Toha Putra, 2004), 73.
} 
memperoleh tanah di Khaibar yang belum pernah saya peroleh harta yang lebih baik bagiku melebihi tanah tersebut, apa perintah engkau kepadaku mengenainya? Nabi saw menjawa, "Jika mau, kamu tahan pokoknya dan kamu sedekahlah hasilnya. Kemudian Umar melakukan shadaqah, tidak dijual, tidak dihibahkan dan tidak pula diwariskan. Berkata Ibnu Umar: Umar menyedekahkannya kepada orang-orang fakir, kaum kerabat, budak belian, sabilillah, ibnu sabil dan tamu. Dan tidak mengapa atau tidak dilarang bagi yang menguasai tanah wakaf itu makan dari hasilnya dengan cara yang baik atau makan tidak bermaksud menumpuk harta."(HR Al-Muslim).

Wakaf dijelaskan secara gamblang melalui aktivitas Umar dalam mewakafkan tanah di Khaibar dengan ketentuan harta pokoknya tetap dan hasilnya dapat dikeluarkan. Dengan mekanisme tersebut, pokok harta akan dijamin kelestariannya dan hasilnya usaha atas pengunaannya tanah tersebut dapat dipakai untuk mendanai kepentingan umat. ${ }^{15}$

Praktik wakaf memerlukan rukun yang harus memenuhi persyaratanpersyaratan tertentu. Rukun dan syarat-syarat yang dimaksud adalah sebagai berikut, ${ }^{16}$

1. Wakif (Orang yang mewakafkan harta)

Waqif disyaratkan harus seseorang yang dipandang ckap untuk melakukan amal kebajikan (ahl li al-tabarru) dengan kriteria sebagai berikut:

a. Dewasa (Baligh)

Wakaf yang dilakukan oleh seseorang yang belum dewasa (baligh), hukumnya tidak sah karena ia dipandang tidak cakap melakukan akad dan tidak cakap pula menggugurkan hak miliknya.

b. Berakal sehat

Orang yang sakit ingatan (majnun) semua tindakannya tidak dapat dipertanggung jawabkan, oleh karena itu tidak sah beramal wakaf.

c. Tidak berada dibawah pengampuan (Boros/lalai)

Orang yang berada dubawah pengampuan dipandang tidak cakap untuk berbuat kebaikan (tabarru'), maka wakaf yang dilakukan hukumnya tidak sah.

2. Mauquf Bih (Barang atau harta yang diwakafkan)

Dalam mewakafkan harta, agar dianggap sah. Maka harus memenuhi beberapa syarat, yaitu:

a. Harta wakaf memiliki nilai.

b. Harta wakaf jelas bentuknya.

c. Harta wakaf merupakan hak milik dari wakif.

d. Harta wakaf berupa benda yang tidak bergerak, seperti tanah atau benda yang disesuaikan dengan kebiasaan wakaf yang ada.

3. Mauquf'Alaih (Penerima wakaf)

Orang maupun Badan Hukum atau Lembaga yang berhak menerima harta wakaf juga memiliki ketentuan dan syarat-syarat, diantaranya:

\footnotetext{
15 Rachmadi Usman, Hukum Perwakafan di Indnesia, (Jakarta: Sinar Grafika, 2013 ), 52.

16 Achmad Djunaidi, Thobieb Al Asyhar, Menuju Era Wakaf Produktif, (Depok: Mumtaz Publishing, 2007), 3 .
} 
a. Harus dinyatakan secara tegas pada waktu mengikrarkan wakaf, kepada siapa/apa ditujukan wakaf tersebut, orangnya jelas dan bukan orang yang tidak diketahui.

b. Pihak yang diberi wakaf adalah pihak yang berorientasi pada kebijakan dan ibadah.

c. Sasaran tersebut diarahkan pada aktivitas kebajikan yang berlanjut atau bersambung.

d. Barang yang telah diwakafkan tidak kembali pada si wakif.

e. Hendaknya wakif ada ketika wakaf tersebut terjadi.

4. Shigat (Pernyataan atau ikrar wakaf)

Secara garis umum, syarat sahnya shigat (ijab), baik berupa ucapan maupun lisan yaitu:

a. Shigat harus munjazah (Seketika/selesai).

b. Shigat tidak diikuti syarat palsu.

c. Shigat tidak diikuti pembatasan waktu tertentu dengan kata lain bahwa wakaf. tersebut tidak untuk selamanya.

d. Tidak mengandung suatu pengertian untuk mencabut kembali wakaf yang sudah dilakukan.

5. Nadzir (Pengelola wakaf)

Nadzir (Pengelola wakaf) baik berupa lembaga atau perorangan yang bertanggung jawab untuk mengelola dan mengembangkan serta menyalurkan hasil-hasil wakaf sesuai dengan peruntukkannya.

a. Syarat Moral

1) Paham tentang hokum Zakat, Infaq, Shadaqah dan Wakaf (ZISWAF).

2) Jujur, amanah dan adil.

3) Tahan godan menyangkut perkembangan usaha.

4) Pilihan, sungguh-sungguh dan menyukai tantangan.

5) Punya kecerdasan, baik emosional maupun spiritual.

b. Syarat Manajemen

1) Mempunyai kapasitas dan kapabilitas yang baik.

2) Dalam leadership.

3) Visioner.

4) Mempunyai kecerdasan yang baik secara intelektual, sosial dan pemberdayaan.

5) Professional dalam pengelolaan harta.

c. Syarat Bisnis

1) Mempunyai keinginan.

2) Mempunyai pengalaman dan siap dimagangkan.

3) Punya ketajaman melihat peluang usaha sebagaimana layaknya entrepreneur.

Wakaf produktif secara terminologi adalah transformasi (proses penambahan nilai) dari pengelolaan wakaf yang alami menjadi professional untuk meningkatkan atau menambah manfaat nilai wakaf. Wakaf produktif adalah sebuah cara pengelolaan wakaf yang berasal dari umat dan memproduktifkan wakaf tersebut dalam arti mendatangkan aspek ekonomi. Dari pengelolaan wakaf produktif tersebut diharapkan mampu menghasilkan keuntungan yang berkelanjutan. Keuntungan ini yang nantinya dapat el-Qisț: Journal of Islamic Economics and Business (JIEB) 
dimanfaatkan untuk memenuhi kebutuhan para pihak yang berhak menerima manfaatnya, sehingga dalam batasan-batasan tertentu, wakaf telah berfungsi untuk menyejahterahkan masyarakat. ${ }^{17}$

Mengenai harta wakaf yang termasuk dalam wakaf produktif antara lain wakaf uang dan surat berharga, wakaf satuan rumah susun, wakaf tanah, wakaf benda bergerak seperti air, bahan bakar minyak dan kendaraan, serta wakaf hak atas kekayaan intelektual. Tradisi pengembangan wakaf yang dikelola kemudian memunculkan berbagai fenomena yang mengakibatkan perwakafan di Indonesia mengalami perkembangan yang menggembirakan. ${ }^{18}$ Sehingga lahirlah Undang-Undang No. 41 Tahun 2004 tentang Wakaf, perwakafan mulai terus dibenahi dengan melakukan pembaharuan di bidang pengelolaan dan pengembangan paham wakaf secara umum.

Suatu pengelolaan dan pengembangan wakaf dibutuhkan manajemen yang baik dan benar. Manajemen adalah proses perencanaan, pengorganisasian dan upaya pengendalian anggota organisasi dan penggunaan sumber daya organisasi lainnya demi tercapainya tujuan organisasi yang akan dicapai. ${ }^{19}$ Manajemen pengelolaan wakaf produktif dapat meningkatkan kualitas perwakafan sebagai dana umat yang produktif dan potensial. Sistem manajemen pengelolaan terdapat beberapa prinsip-prinsip diantaranya sebagai berikut:20

\section{Perencanaan (Planning)}

Perencanaan merupakan suatu proses menentukan sasaran yang ingin dicapai, tindakan yang seharusnya dilaksanakan, bentuk organisasi yang tepat untuk mencapainya dan sumber daya manusia yang bertanggung jawab terhadap kegiatan-kegiatan yang akan dilakukan.

2. Pengorganisasian (Organizing)

Organisasi merupakan proses kegiatan penyusunan struktur organisasi sesuai dengan tujuan-tujuan, sumber-sumber dan lingkungannya. Tujuan pengorganisasian untuk merancang suatu tim kerjasama, mengatur otoritas dan komunikasi sumber daya manusia.

3. Pelaksanaan (Actuating)

Pelaksanaan adalah suatu tindakan dari sebuah rencana yang sudah disusun secara matang dan terperinci, impelementasi biasanya dilakukan setelah perencanaan sudah dianggap siap.

4. Pengawasan (Controling)

Pengawasan adalah proses dalam menetapkan ukuran kinerja dan pengambilan tindakan yang dapat mendukung pencapaian hasil yang diharapkan sesuai dengan kinerja yang telah ditetapkan.

\footnotetext{
17 Direktorat Pemberdayaan Wakaf, Direktorat Jendral Bimbingan Masyarakat Islam, Strategi Pengembangan Wakaf Tunai di Indonesia, (Jakarta: Departemen RI, 2007), 1.

18 Mukhlisin Muzarie, Hukum Perwakafan dan Implikasinya Teradap Kesejahteraan Masyarakat, (Jakarta: Kementerian Agama RI, 2010), 118.

19 Sukarna, Dasar-dasar Manajemen, (Bandung: CV. Mandar Maju, 2011), 2.

${ }^{20}$ George R. Terry, Prinsip-prinsip Manajemen, (Jakarta: Bumi Aksara, 1993), 9.
} 


\section{SOCIAL ENTREPRENEUR}

Social entrepreneur merupakan sebuah istilah turunan dari entrepreneur. Gabungan dari dua kata, social yang memiliki arti kemasyarakatan, dan entrepreneur yang artinya kewirausahaan. Social entrepreneur adalah seseorang yang memahami permasalahan sosial yang sedang terjadi dan berusaha melakukan perubahan sosial (social change) dengan menggunakan kemampuan entrepreneurs yang dimiliki. Terutama meliputi bidang kesejahteraan, ekonomi, pendidikan dan kesehatan. ${ }^{21}$

Social entrepreneur atau kewirausahaan sosial juga diartikan sebagai suatu proses yang melibatkan penggunaan dan penggabungan sumber daya secara inovatif untuk membuka peluang dalam mempercepat perubahan sosial atau memenuhi kebutuhan sosial. Definisi tersebut memberikan pemahaman bahwa social entrepreneur terdiri dari empat elemen utama yakni: ${ }^{22}$

1. Social Value

Elemen paling khas dari social entrepreneur dengan menciptakan manfaat sosial yang nyata bagi masyarakat dan lingkungan sekitar.

2. Civil Value

Social entrepreneur pada umumnya berasal dari inisiatif dan partisipasi masyarakat sipil dengan mengoptimalkan modal sosial yang ada di masyarakat.

3. Innovation

Melalui inovasi dapat memecahkan masalah sosial dengan cara-cara inovatif antara lain dengan memadukan kearifan lokal dan inovasi sosial.

4. Economic Activity

Social entrepreneur yang berhasil pada umumnya dengan menyeimbangkan antara aktivitas sosial dan aktivitas bisnis. Aktivitas bisnis dalam ekonomi dikembangkan untuk menjamin kemandirian dan keberlanjutan misi sosial suatu organisasi.

Adanya social entrepreneur inilah yang memunculkan usaha untuk saling tolong menolong antar masyarakat. Misi sosial yang dimiliki oleh social entrepreneur menjadi wujud dari upaya untuk menolong orang lain yang sedang dalam masalah sosial dengan mengaitkan aktivitas bisnis sebagai solusinya. Hal ini pun selaras dengan apa yang diajarkakan Islam, Islam mengajarkan kepada orang-orang beriman untuk saling tolong menolong dan melindungi saudaranya yang lain. Sebagaimana firman Allah SWT dalam surat At-Taubah ayat 71: ${ }^{23}$

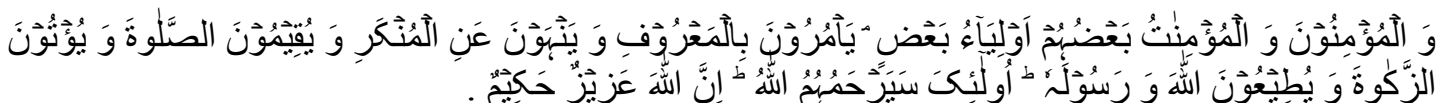

\footnotetext{
${ }^{21}$ Irma Paramita Sofia, Model Kewirausahaan Sosial (Social Entrepreneurship) Sebagai Gagasan Inovasi Sosial Bagi Pembangunan Perekonomian, Jurnal Universitas Pembangunan Jaya, Vol. 2, No. 1, (2015), 5 .

22 Hery Wibowo dan Soni A. Nulhaqim, Kewirausahaan Sosial: Merevolusi Pola Pikir dan Menginisiasi Mitra Pembangunan Kontemporer, (Bandung: UNPAD Press, 2015), 9.

23 Departemen Agama RI, Al-Quran Special for Muslimah, (Jakarta: Cordoba, 2016), 198.
} 
"Dan orang-orang yang beriman, laki-laki dan perempuan, sebagian mereka menjadi penolong bagi sebagian yang lain. Mereka menyuruh (berbuat) yang makruf dan mencegah yang mungkar, melaksanakan shalat, menunaikan zakat dan taat kepada Allah SWT dan Rasul-Nya. Mereka akan diberi rahmat oleh Allah SWT. Sungguh, Allah Maha Perkasa, Maha Bijaksana.”

Ayat diatas mengingatkan bahwa sesungguhnya orang-orang yang beriman harus saling menolong dan melindungi. Seorang mukmin dengan mukmin yang lain diibaratkan seperti suatu bangunan yang harus saling menguatkan, sehingga saat salah satu berada dalam kesulitan sudah seharusnya bagi yang lain juga turut membantu. Begitulah Islam menumbuhkan kesadaran akan tanggung jawab sosial dalam jiwa setiap muslim dan mendorong setiap muslim untuk berpartisipasi nyata dalam membantu saudaranya yang lain. Dengan begitu diharapkan semua individu dalam masyarakat akan saling menopang dan bersinergi untuk menciptakan kesejahteraan bersama. ${ }^{24}$

\section{CASH WAQF LINKED SOCIAL ENTREPRENEUR}

Konsep wakaf uang tunai berawal dari wakaf produktif yang berarti banyak menghasilkan yang bersifat mampu berproduksi. ${ }^{25}$ Manusia produktif secara definitive adalah kelompok entrepreneur yang berciri antara lain peka terhadap kebutuhan lingkungan sekelilingnya, menguasai informasi dan memiliki dinamika kreatifitas yang tinggi. Sehingga mampu menciptakan bukan hanya mencari lapangan pekerjaan saja tapi juga menumbuhkan wawasan ekonomi yang luas. ${ }^{26}$ Berarti wakaf produktif adalah wakaf yang pokok barangnya digunakan untuk kegiatan produksi dan keuntungannya diberikan sesuai dengan tujuan wakaf.

Perkembangan wakaf produktif di Indonesia berjalan menuju arah yang positif. Banyak sekali pesantren, masjid ataupun badan ZISWAF yang mulai mengembangkan wakaf produktif. Bentuk dari wakaf produktif sangatlah beragam, salah satunya penggagas cash wakaf linked social entrepreneur di Malang adalah Yayasan Universitas Islam Malang (UNISMA). Seperti yang dilakukan oleh nadzir wakaf beserta pengelola yakni di Yayasan UNISMA, mereka mengembangkan wakaf produktif pada beberapai unit usaha yaitu Ruang Rawat Inap kelas Very Important Person (VIP) di Rumah Sakit UNISMA Malang serta Minimarket Al-Khaibar di Jalan Tata Surya Malang.

Pengelolaan wakaf yang dilakukan oleh Yayasan Universitas Islam Malang (UNISMA) dimulai ketika tahun 2006 mereka mendapatkan dana wakaf produktif sebesar Rp. 2.000.000.000,- dari Kementerian Agama. Dalam memanfaatkan amanah ini agar lebih produktif, nadzir Yayasan UNISMA memandatkannya untuk membangun Gedung Very Important Person (VIP) di Rumah Sakit UNISMA di atas tanah seluas $600 \mathrm{~m}^{2}$. Penetapan dana bantuan

\footnotetext{
24 Wahbah Az-Zuhaili, Fiqh Islam Wa Adillatuhu, (Jakarta: Gema Insani, 2011), 63.

25 Partanto dan Dahlan Al-Barry, Kamus Ilmiah Populer, (Yogyakarta: Arkol, 1994), 626.

${ }^{26}$ Sahl Mahfud, Nuansa Fiqh Sosial, (Yogyakarta: LKiS, 2004), 151.
} 
tersebut disahkan melalui Surat Keputusan Dirjen Bimas Islam No. Dj. II/243/2006. Proyek tersebut diketuai oleh Zawawi Mukhtar selaku nadzir.

Sukses dengan pengelolaan wakaf produktif berupa ruang VIP di Rumah Sakit UNISMA, nadzir terus berfikir untuk lebih mengembangkan wakaf produktif ini guna pemberdayaan umat. Selanjutnya, dipilihlah untuk membangun minimarket. Minimarket pertama yang diberi nama Al-Khaibar itu berlokasi di Jalan Tata Surya Malang, minimarket kedua berlokasi di sebelah Masjid Rois Dahlan Malang, minimarket ketiga berlokasi di Masjid Sabilillah Malang, minimarket keempat hasil kerjasama dengan Pondok Pesantren AlKharomain yang berlokasi di Pujon Malang, minimarket keempat hasil kerjasama dengan investor AT Mart yang berlokasi di Jalan Bondowoso Malang, dan minimarket terakhir hasil kerjasama dengan investor Koperasi Warga BB Mart yang berlokasi di Jalan Bantaran Malang.

Pemilihan untuk mengembangkan wakaf produktif melalui bisnis minimarket mendapat respon positif dari masyarakat dikarenakan minimarket ini tidak sekedar menyediakan kebutuhan masyarakat dengan harga terjangkau dan membuka lapangan pekerjaan, namun juga karena perannya dalam kegiatan sosial yang berdampak pada pengentasan kemiskinan masyarakat sekitar. Terkait berbagai definisi diatas bahwa kesuksesan wakaf produktif melalui bisnis minimarket oleh Yayasan UNISMA tidak terlepas dari manajemen pengelolaan dan pengembangannya. Manajemen pengelolaan dan pengembangan wakaf produktif harus mempunyai visi yang jelas dan terarah dalam pengelolaan harta wakaf, khususnya tanah wakaf produktif yang strategis agar dapat mencapai tujuan yang diharapkan.

Visi adalah suatu inti yang sangat diperlukan karena untuk menggali potensi dan membuka peluang yang ada dalam rangka menambah values (nilai) wakaf untuk kepentingan masyarakat banyak. Ketiadaan visi dalam manajemen pengelolaan akan menciptakan suasana atau iklim yang tidak menguntungkan bahkan merugikan sama sekali. Pada minimarket Al-Khaibar ini tentunya selain memiliki visi yang ditempatkan sebagai salah satu sarana ibadah dalam pengelolaannya tetapi juga adanya misi yang menjadikan sumber dalam meningkatkan kesejahteraan masyarakat, memberikan manfaat kepada umat dan membantu banyak hal dalam memenuhi kebutuhan hajat manusia. Tertulis pada beberapa sticker pada bangunan minimarket Al-Khaibar di pintu masuk seperti "Belanja Murah, Layanan Ramah, Menjadi Berkah.”

Dalam penelitian ini peneliti mendapatkan informasi dari beberapa informan yang terdiri dari nadzir, sekretaris, manajer minimarket Al-Khaibar, pegawai minimarket Al-Khaibar, serta mauquf 'alaih. Untuk informasi tentang manajemen pengelolaan dan pengembangan wakaf produktif dalam bentuk usaha minimarket Al-Khaibar. Berdasarkan hasil penelitian yang dilakukan pada minimarket Al-Khaibar yaitu terdapat model manajemen wakaf produktif minimarket berdasarkan prinsip-prinsip berikut,

Adapun tahap pertama adalah perencanaan. Perencanaan merupakan suatu proses menentukan sasaran yang ingin dicapai, tindakan yang seharusnya dilaksanakan, bentuk organisasi yang tepat untuk mencapainya dan sumber daya manusia yang bertanggung jawab terhadap kegiatan-kegiatan yang akan 
dilakukan. ${ }^{27}$ Perencanaan awal dari wakaf produktif minimarket Al-Khaibar diawali oleh pengajuan pengelolaan dana wakaf Kementerian Agama oleh Yayasan Universitas Islam Malang (UNISMA). Kemudian Yayasan UNISMA membentuk nadzir yang nantinya akan mengelola dana wakaf tersebut dan dana wakaf sebesar Rp. 2.000.000.000 diberikan oleh Kementerian Agama. Yayasan UNISMA mendapat pengesahan melalui surat keputusan Badan Wakaf Indonesia (BWI) Perwakilan Jawa Timur yang saat ini bernomor 18/BWIJTM/NZ/VI/2015 karena adanya pembaharuan surat keputusan tiap 5 tahun sekali. ${ }^{28}$

Badan Wakaf Indonesia memiliki peran sebagai legislator dan fasilitator pengembangan wakaf produktif di UNISMA. Dalam surat keputusan tersebut, tertulis tugas dan tanggung jawab nadzir, yaitu:

1. Melakukan pengadministrasian harta benda wakaf.

2. Mengelola dan mengembangkan harta benda wakaf sesuai dengan tujuan, fungsi dan peruntukannya.

3. Mengawasi dan melindungi harta benda wakaf.

4. Menyampaikan laporan tertulis kepada Badan Wakaf Indonesia Perwakilan Jawa Timur.

Dana wakaf tersebut awalnya dikelola untuk pembangunan ruang rawat inap VIP di Rumah Sakit UNISMA. Setelah pembangunan dari ruang rawat inap VIP mengalami BEP, nadzir mulai mengembangkan dana wakaf tersebut dan mengamati sebuah trend di masyarakat yang menyukai berbelanja di minimarket. Hingga akhirnya muncul sebuah ide untuk membangun usaha minimarket melalui pengembangan dana wakaf produktif tersebut. Selain modal berupa dana, ada modal lain yang dibutuhkan untuk membangun minimarket yaitu lahan yang akan dibangun minimarket. Kriteria-kriteria tersebut adalah sebagai berikut: 29

1. Sampai saat ini tanah yang dipilih adalah tanah wakaf atau tanah dalam komplek masjid yang tidak memiliki masalah sengketa. Tujuan dari pemilihan tanah wakaf atau dalam komplek masjid selain untuk meminimalisir anggaran untuk membeli tanah, pemilihan tanah-tanah tersebut juga akan meminimalisir risiko tanah tersebut dijual atau dialih fungsikan.

2. Lokasi tanah tersebut haruslah memiliki potensi. Memilih tanah haruslah menghitung produktivitas dan untung rugi dari pemilihan lokasi. Market share merupakan salah satu poin yang sangat dipertimbangkan.

Setelah dana dan tempat telah tersedia, maka nadzir mengajukan izin usaha. Dikarenakan bertempat di Kota Malang, maka nadzir mengajukan izin usaha pada Badan Pelayanan Perizinan Terpadu Pemerintah Kota Malang dengan persyaratan sebagai berikut:

1. Izin Mendirikan Bangunan (IMB)

2. Hinderordonnantie (HO) atau bisa disebut surat izin gangguan

3. Nomor Pokok Wajib Pajak (NPWP)

\footnotetext{
27 Yayat M. Herujito, Dasar-dasar Manajemen, (Jakarta: RajaGrafindo Persada, 2001), 7.

${ }_{28}$ Achmad Zawawi Mochtar, Ketua Nadzir, Wawancara, (Malang, 9 Januari 2020).

29 Chusnul Faizah, Sekretaris Administrasi, Wawancara, (Malang, 9 Januari 2020).
} 
4. Denah Toko

5. Identitas dari pemilik (Ketua Nadzir)

6. Permodalan

Tahap kedua adalah pengorganisasian. Pengorganisasian adalah proses kegiatan penyusunan struktur organisasi sesuai dengan tujuan-tujuan, sumbersumber dan lingkungannya. Tujuan pengorganisasian untuk merancang suatu tim kerjasama, mengatur otoritas dan komunikasi sumber daya manusia. ${ }^{30}$ Karena pentingnya pengorganisasian, maka struktur organisasi perlu untuk dibuat. Begitu pula dalam berbisnis, perlu adanya struktur organisasi, termasuk di minimarket Al-Khaibar. Struktur organisasi minimarket Al-Khaibar menjelaskan berbagai uraian tugas dan jabatan pengelola, yakni sebagai berikut: 31

Gambar 2. Struktur Organisasi Minimarket Al Khaibar

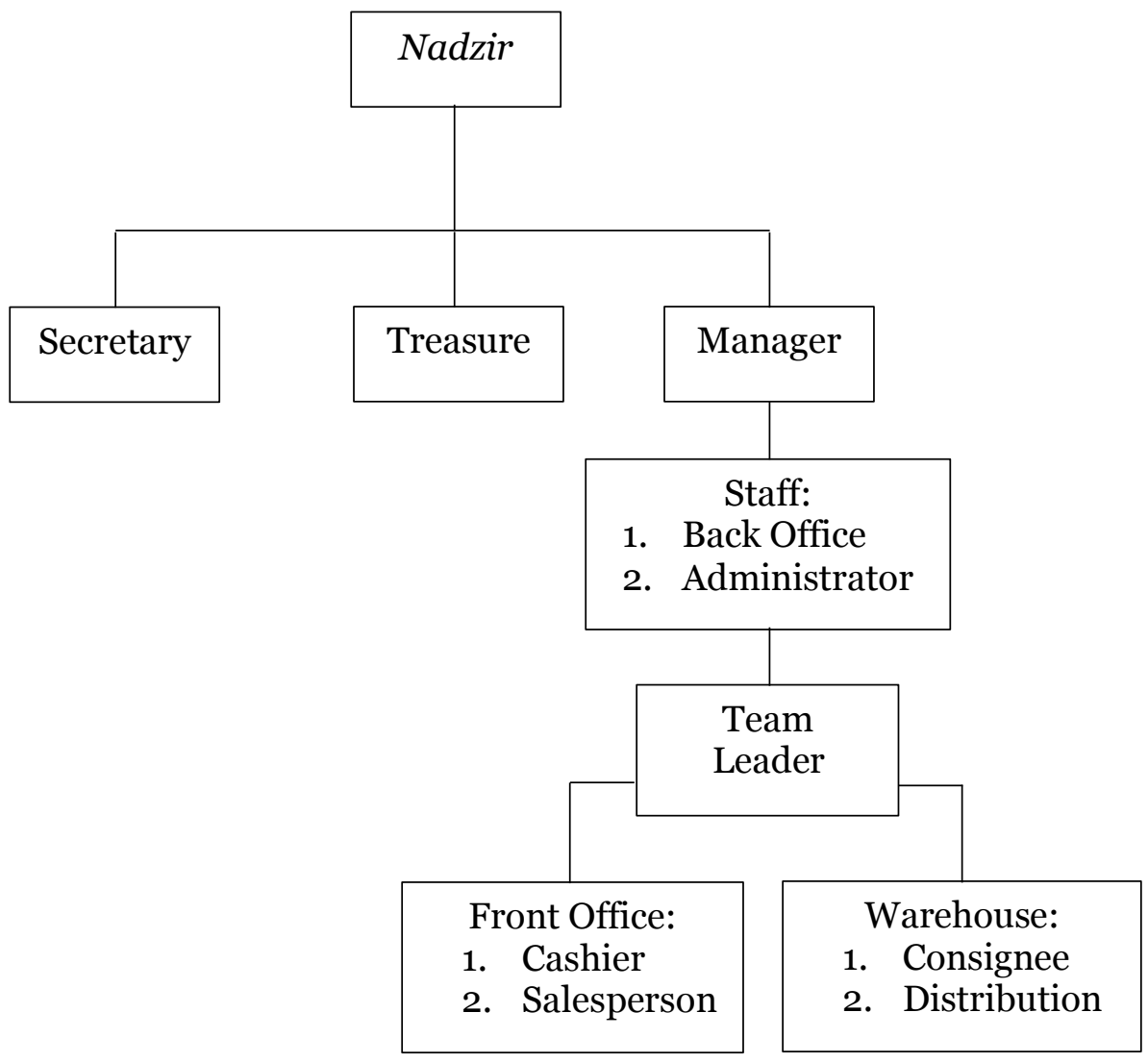

Sumber: Data diolah oleh Peneliti

Nadzir terdiri dari:

Dewan Pakar I : Prof. Dr. KH. Mohammad Tholhah Hasan

Dewan Pakar II : Prof. Dr. H. A. Sodiki, SH

${ }^{30}$ Wirnardi, Kepemimpinan dalam Manajemen, (Jakarta: Rineka Cipta, 2000), 56.

${ }^{31}$ Achsan Djauhari, Manajer, Wawancara, (Malang, o9 Januari 2020) 
Ketua

Sekretaris

: H. A. Zawawi Mochtar, SH

Bendahara

: Drh. H. Zainul Fadli, M. Kes

: Prof. Dres. H. Junaedi Mistar, Phd.

Untuk masing-masing bagian, memiliki tugas sebagai berikut:

1. Dewan Pakar I : Konsultan hokum-hukum agama atau fiqh.

2. Dewan Pakar II : Konsultan hokum Undang-undang wakaf.

3. Ketua Nadzir : Bertanggung jawab atas pengelolaan bisnis dari wakaf produktif.

4. Secretary : Membantu pekerjaan ketua nadzir untuk mengelola, melakukan korespondensi yaitu mencatat dan menerima surat yang datang dan pengarsipan berkas.

5. Treasure : Membuat pembukuan dan mengatur keuangan wakaf produktif.

6. Manager : Mengawasi semua karyawan yang ada dibawahnya.

7. Team Leader : Mengkoordinir semua karyawan yang ada dibawahnya.

8. Cashier : Melayani konsumen terkait transaksi pembelian.

9. Salesperson : Menyiapkan barang untuk display.

10. Back Office : Input dan Checking data pembelian dan transaksi pembelian.

11. Administrator : Order barang, menangani tagihan supplier, input jumlah barang.

12. Consignee kesesuaian jumlah

: Menerima barang yang dipesan dan mengecek dan jenis barang.

13. Distribution : Penyaluran atau pengiriman barang ke cabang-cabang minimarket ataupun konsumen.

Dalam pengorganisasian tersebut dapat pula diartikan sebagai suatu keseluruhan yang didalamnya termasuk fasilitas, material, dan orang dengan perilakunya yang diatur menurut posisi berdasarkan tugas pekerjaan. Struktur organisasi merupakan bentuk kerjasama dari berbagai pihak yang didasarkan menurut pola yang sama-sama memiliki tujuan yang sama seperti menghendaki adanya tertib, memiliki tujuan dalam berorganisasi, penugasan tanggung jawab tertentu, dan pendelegasian wewenang yang diperlukan untuk melaksanakan masing-masing tugas perindividu. Tataran karyawan bisa saja berubah-ubah sesuai kondisi kinerja karyawan yang dibutuhkan dilihat melalui absensi disetiap harinya, karena setiap karyawan mendapatkan hari libur yag berbedabeda dengan mengkondisikan keperluan karyawan satu sama lain. ${ }^{2}$

Untuk mendapatkan karyawan yang berkapasitas sesuai yang dibutuhkan, tentunya diawali sejak penerimaan karyawan. Informasi lowongan pekerjaan minimarket Al-Khaibar dilakukan dengan berbagai cara. Mulai dari mulut ke mulut, social media platform facebook, hingga informasi di grup lowongan kerja Malang. Perekrutan karyawan bergantung dari kebutuhan minimarket Al-Khaibar. Ketika yang dibutuhkan adalah kasir, maka karyawan akan ditanyakan kesanggupannya untuk menempati posisi sebagai kasir. Begitu pula dengan yang lain ketika yang dibutuhkan adalah pramuniaga dan lain

${ }^{32}$ Chusnul Faizah, Sekretaris Administrasi, Wawancara, (Malang, 9 Januari 2020) 
sebagainya.33 Proses dalam penerimaan karyawan minimarket Al-Khaibar tidak jauh berbeda dengan perusahaan yang lain. Proses tersebut yaitu: 34

a) Pertama, mengajukan surat lamaran pekerjaan di minimarket pusat di Jalan Tata Surya, Malang. Surat lamaran tersebut berisi, biodata diri, ijazah terakhir, SKCK, dan foto.

b) Kedua, mengikuti wawancara, manajer menjelaskan tentang sistem kerja minimarket Al-Khaibar, kesanggupan bekerja di minimarket Al-Khaibar dan memberitahukan rincian gaji.

c) Menghubungi karyawan yang lolos tes wawancara.

Tahapan ketiga adalah pelaksanaan. Pelaksanaan adalah suatu tindakan dari sebuah rencana yang sudah disusun secara matang dan terperinci, impelementasi biasanya dilakukan setelah perencanaan sudah dianggap siap. Dalam operasionalnya, bisnis tentu membutuhkan Standard Operational Procedure (SOP). SOP diperlukan oleh perusahaan sebagai acuan kerja untuk karyawan dalam melakukan kegiatannya sehingga diharapkan dari hal tersebut akan menghasilkan sumber daya manusia yang handal dan professional. Tujuan dari penyusunan SOP adalah untuk mengontrol kegiatan dalam perusahaan melalui panduan kerja yang nantinya diharapkan target perusahaan akan tercapai maksimal. SOP juga berdampak dalam pertumbuhan bisnis perusahaan karena evaluasi kinerja operasional.

Dalam pelaksanaannya, minimarket Al-Khaibar memiliki Standard Operational Procedure (SOP) untuk masing-masing tugas karyawan maupun untuk manajemen di minimarket baik untuk keuangan maupun penataan barang. Namun SOP ini memang belum dibuat secara tertulis, para karyawan mengetahui SOP perusahaan melalui training selama 3 bulan yang diberikan oleh minimarket Al-Khaibar ketika awal kontrak bekerja. Nadzir juga melaksanakan strategi pemasaran yang digunakan untuk memperkenalkan minimarket Al-Khaibar kepada masyarakat. Strategi pemasaran tersebut sebagai berikut:35

1. Pembuatan Brosur dan Banner

2. Sosialisasi Wakaf Produktif

3. Melaksanakan kegiatan-kegiatan Islam

4. Mengadakan Bakti Sosial

5. Melalui sponsor-sponsor

6. Pelayanan kepada Mahasiswa, Peserta Studi Banding, Instansi Pemerintah ataupun Lembaga dan juga Organisasi Keagamaan.

Minimarket Al-Khaibar juga lebih menghargai umat Islam pada kepatuhan pelayanan dalam artian seperti ketika hari jumat minimarket AlKhaibar akan tutup sebelum sholat jumat hingga selesai sholat jumat, dari pelayanannya pun juga ramah ketika melayani konsumen atau pembeli yang ingin membeli sesuatu, dan dari sinilah terlihat adanya keadilan dan terdapat keberkahan serta menjadi nilai ibadah ketika berbelanja di minimarket Al-

\footnotetext{
33 Muhammad Muhdlor, Team Leader, Wawancara, (Malang, o9 Januari 2020)

34 Achsan Djauhari, Manajer, Wawancara, (Malang, o9 Januari 2020)

${ }^{35}$ Ibid,.
} 
Khaibar. Hal ini sama saja ikut melestarikan dan membantu perkembangan wakaf produktif yang sedang berjalan.

Tahapan terakhir adalah pengawasan. Pengawasan adalah proses dalam menetapkan ukuran kinerja dan pengambilan tindakan yang dapat mendukung pencapaian hasil yang diharapkan sesuai dengan kinerja yang telah ditetapkan. Sistem kontrol dalam minimarket Al-Khaibar dilakukan secara internal dan eksternal. Secara internal, pengawasan yang dilakukan adalalah pengawasan yang dilakukan oleh manajer kepada karyawan minimarket Al-Khaibar. Hal tersebut setidaknya dilakukan sekali dalam satu minggu, manajer mendatangi cabang-cabang minimarket untuk mengontrol keadaan minimarket. Manajer biasanya menanyakan perihal karyawan, barang, perkembangan dan keadaan minimarket. Selain kunjungan langsung ke cabang-cabang minimarket, briefing yang dilakukan oleh manajer, setidaknya satu bulan sekali. Hal tersebut merupakan sebuah moment untuk melakukan evaluasi kinerja dari seluruh minimarket Al-Khaibar selama satu bulan terakhir.

Selain pengawasan secara internal, ada juga pengawasan yang dilakukan secara eksternal yaitu melalui pihak ketiga. Pengawasan tersebut dilakukan melalui pertemuan tiga bulan sekali yang dilakukan Yayasan UNISMA. Pada pertemuan tersebut, para pengelola wakaf produktif akan membahas mengenai kinerja keseluruhan. Hal tersebut dilakukan dengan mengecek laporan keuangan dari minimarket Al-Khaibar apakah wajar atau tidak. Selain itu, Kementerian Agama juga melakukan pengawasan melalui laporan yang dibuat oleh nadzir. Nadzir memiliki kewajiban untuk melaporkan pengelolaan wakaf produktif kepada wakif yakni Kementerian Agama dan juga kepada Badan Wakaf Indonesia. 36

Gambar 2. Distribusi Manfaat Hasil Pengelolaan Wakaf Produktif

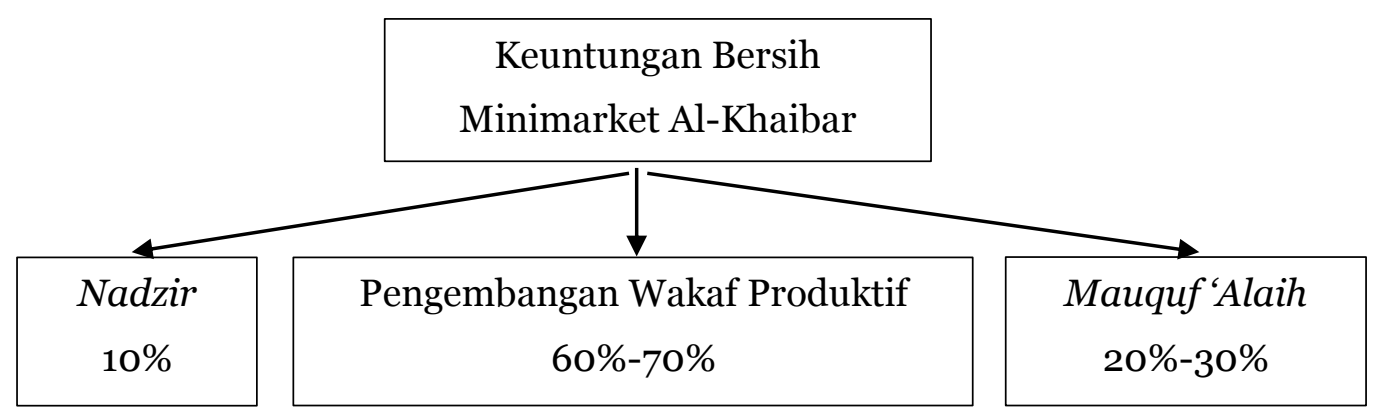

Sumber: Data diolah oleh Peneliti

Tujuan akhir dari pengelolaan wakaf produktif tersebut untuk memberikan kesejahteraan pada umat masyarakat. Namun tidak semua hasil keuntungan yang didapat dari minimarket Al-Khaibar lantas langsung diberikan kepada mauquf 'alaih. Menurut nadzir, ada manajemen wakaf yang diterapkan dalam mengelola hasil keuntungan dari minimarket Al-Khaibar.

${ }^{36}$ Achmad Zawawi Mochtar, Ketua Nadzir, Wawancara, (Malang, 9 Januari 2020) 
Keuntungan yang dimaksud nadzir adalah keuntungan bersih yang dihasilkan minimarket Al-Khaibar secara keseluruhan. Keuntungan bersih adalah pendapatan hasil usaha yang diperoleh minimarket Al-Khaibar dikurangi gaji karyawan, kebutuhan administrasi, biaya listrik, air dan juga lainnya. Dari keuntungan bersih ini, 20\% -30\% dibagikan kepada mauquf 'alaih, 10\% untuk nadzir sesuai dengan Undang- undang Wakaf No. 41 tahun 2004 pasal 12, dan 60\%-70\% untuk pengembangan wakaf produktif. Pemberian 20\% untuk mauquf 'alaih bukanlah hal yang pasti. Ketika ternyata keuntungan bersih dari minimarket Al-Khaibar banyak, maka bisa bertambah hingga 30\%. Jadi nilai 20\% adalah nilai minimal yang akan didistribusikan. 37

Berdasarkan apa yang disampaikan oleh nadzir, mauquf 'alaih minimarket Al-Khaibar adalah sebagai berikut:

1. Guru-guru Diniyah pada:

a. Madrasah Diniyah Nurul Hidayah

b. Madrasah Diniyah Masjid Besar Rois Dahlan

2. Petugas Khotib Masjid Ainul Yaqin UNISMA

3. Imam Masjid Besar Rois Dahlan

4. Imam Masjid Sabilillah

5. Tenaga kebersihan Masjid Besar Rois Dahlan

6. Tenaga kebersihan Masjid Sabilillah

7. Bantuan Sosial pada:

a. Ketua RT 02 RW 06 Kel. Dinoyo

b. Ketua RT 01 RW o4 Kel. Dinoyo

8. Bantuan kepada BWI Perwakilan Jawa Timur

9. Santunan untuk anak yatim

10. Bantuan umrah untuk pegawai RS UNISMA dan Minimarket Al-Khaibar

11. Manajemen minimarket investor pada minimarket Al-Khaibar di Pondok Pesantren Al-Kharomain, Koperasi Warga BB Mart Bantaran dan AT Mart Bondowoso

Seperti yang terealisasi sebelumnya yakni masjid Rois Dahlan sebagai salah satu mauquf 'alaih telah menerima mauquf'alaih sejak minimarket AlKhaibar di jalan Tata Surya berdiri. Mauquf 'alaih di masjid Rois Dahlan diperuntukkan untuk khatib dan dalam satu tahun terdapat 52 khatib. Pihak Al-Khaibar memberikan mauquf 'alaih kepada masjid Rois Dahlan tiap tiga bulan sekali sebesar Rp 1.500.000,-. Nominal ini tidak berubah semenjak pertama kali diberikan. Menurut Pak Maskuri Bakri jumlah ini tidak memenuhi sepenuhnya bisyarah yang diberikan kepada takmir karena bisyarah yang diberikan kisaran $\mathrm{Rp} 320.000,-\mathrm{s} / \mathrm{d} \mathrm{Rp}$ 400.000,-, namun bantuan dari Al-Khaibar tersebut sudah cukup meringankan. Proses penyerahan mauquf 'alaih dari Al-Khaibar kepada pihak masjid Rois Dahlan tidaklah rumit. Awalnya Al-Khaibar meminta pihak masjid Rois Dahlan untuk menyerahkan Surat Ketetapan (SK) pengurus masjid serta memberikan daftar khatib untuk satu tahun kedepan di awal tahun. Setelah itu, setiap 3 bulan AlKhaibar akan menyerahkan mauquf 'alaih. Pihak masjid Rois Dahlan hanya

37 Chusnul Faizah, Sekretaris Administrasi, Wawancara, (Malang, 9 Januari 2020) 
perlu menandatangani kwitansi tanda terima. 38

Untuk mauquf 'alayh yang yang berasal dari minimarket Al-Khaibar sendiri dengan berbasis wakaf dan bekerjasama dengan mitra, maka nadzir menyerahkannya kepada mitra. Mitra tersebut memiliki keleluasaan untuk menentukan mauquf 'alaih yang dituju. Contohnya mauquf 'alaih yang diberikan kepada masjid Rois Dahlan, masjid Rois Dahlan memanfaatkan untuk meningkatkan kualitas pelayanan masjid Rois Dahlan mulai dari peribadatan hingga kebutuhan jamaah, seperti peralatan dan perlengkapan sholat bagi jamaah pria dan wanita. Disisi lain mauquf 'alaih ini mereka salurkan untuk membuat pertemuan atau majelis taklim, kebersihan dan kenyamanan masjid. Kedepannya masjid Rois Dahlan berharap untuk terus mengembangkan wakaf ini, seperti membuat pujasera dan pengembanganpengembangan bisnis lainnya. 39

Saat ini, dapat dilihat menjamurnya minimarket yang berdiri di tengah kalangan masyarakat. Banyaknya jumlah minimarket tentunya menimbulkan ketatnya persaingan bisnis usaha. Minimarket Al-Khaibar tentu saja memerlukan perencanaan dalam menghadapi persaingan usaha guna mengembangkan wakaf produktif minimarket untuk kedepannya. Menurut nadzir, manajer, serta team leader minimarket Al-Khaibar, strategi untuk menghadapi persaingan usaha yang dilakukan oleh minimarket Al-Khaibar adalah dengan mengembangkan penjualan barang dengan harga yang lebih murah dari minimarket lainnya. Selisih harga barang yang dijual bisa lebih murah mulai dari minimarket lainnya dengan kisaran harga Rp. 100-Rp. 1000. Minimarket Al-Khaibar bisa memberikan harga yang lebih murah disebabkan salah satunya karena mereka bisa mendapatkan barang langsung dari produsen, contohnya saja barang-barang yang diproduksi oleh Unilever dan PT Indomarco. Selain menjual barang dengan harga yang lebih murah, minimarket Al-Khaibar juga berusaha menyamakan kualitas pelayanan konsumen dengan minimarket lainnya. 40

Kedepannya, nadzir juga berharap minimarket Al-Khaibar terus berkembang dan dapat membuka lebih banyak cabang minimarket lainnya. Sampai saat ini, minimarket Al-Khaibar sudah memiliki tiga cabang yang dibangun melalui dana wakaf dan tiga cabang yang merupakan bentuk kerjasama. Tiga cabang yang dibangun dari wakaf uang tunai yakni minimarket pertama yang diberi nama Al-Khaibar itu berlokasi di Jalan Tata Surya Malang dekat dengan Universitas Islam Malang dan masjid Ainul Yaqin, minimarket kedua berlokasi di Jalan Ketawang Gede Malang disamping masjid Rois Dahlan, dan minimarket ketiga dibangun di Jalan A. Yani dalam kompleks masjid Sabilillah. Sedangkan tiga minimarket lainnya yang merupakan kerjasama yaitu dengan pondok pesantren Al-Kharomain di daerah PujonMalang, minimarket AT-Mart yang berlokasi di Jalan Bondowoso Malang dan terakhir Koperasi Warga BB Mart di Jalan Bantaran Malang, Malang. Banyak

${ }^{38}$ Maskuri Bakri, Imam Masjid Besar Rois Dahlan sebagai mauquf'alaih, Wawancara, (Malang, 9 Januari 2020)

39 Bahron, Guru Madin Masjid Besar Rois Dahlan sebagai mauquf'alaih, Wawancara, (Malang, 9 Januari 2020)

${ }^{40}$ Muhammad Muhdlor, Team Leader, Wawancara, (Malang, o9 Januari 2020) 
sekali pihak-pihak yang menawarkan untuk bekerja sama membangun minimarket, baik dari daerah Malang, maupun dari luar daerah kota Malang. Namun nadzir tetap berhati-hati dalam mengambil keputusan untuk bekerjasama.

Bertambahnya aset dan usaha wakaf produktif yang dimiliki oleh yayasan UNISMA merupakan dampak dari manajemen pengelolaan wakaf produktif yang diimplementasikan dalam manajemen dana. Dengan implementasi manajemen pengelolaan dan pengembangan wakaf produktif yang baik maka dapat dinilai suatu lembaga mempunyai kemajuan dalam pencapaian tujuannya. Dalam mengembangkan wakaf produktif minimarket, perlu diperhatikan besarnya risiko dari investasi tersebut. Ada beberapa pertimbangan yang dimiliki oleh nadzir ketika membuka cabang minimarket, diantaranya yaitu: 41

1. Bersedia menggunakan manajemen pengelolaan wakaf produktif, yaitu terkait dengan penyaluran hasil dari pengelolaan dan pengembangan wakaf produktif.

2. Status tanah, meski bukan wakaf namun tanah yang tidak mudah dijual atau dialihkan serta tidak dalam kasus sengketa.

3. Lokasinya strategis, yaitu memiliki peluang market share yang besar.

4. Partner merupakan pihak yang benar-benar dapat dipercaya.

Untuk pihak-pihak yang ingin melakukan kerjasama dengan nadzir Yayasan UNISMA membangun minimarket Al-Khaibar, ada beberapa tahapan yang harus dilalui, diantaranya yaitu:

1. Mengajukan permohonan kerjasama kepada ketua nadzir yayasan UNISMA.

2. Kemudian nadzir menganalisa permohonan dan melakukan pertimbangan seperti yang disebutkan sebelumnya.

3. Selanjutnya nadzir menerima atau menolak permohonan tersebut.

4. Ketika menerima, nadzir akan membuat nota kesepahaman dengan pemohon hingga terbentuk kesepakatan atau bisa juga pemohon membatalkan permohonannya apabila tidak adanya kesepahaman.

5. Ketika telah sepakat, nadzir akan menginvestasikan dana wakaf kepada pemohon sebagai modal untuk membangun gedung minimarket dan isinya serta nantinya juga akan dibangun sistem manajemen pengelolaan dan pengembangannya.

Dari implementasi manajemen pengelolaan dan pengembangan wakaf produktif yang telah dirancang dan dilaksanakan oleh minimarket Al-Khaibar, dapat dilihat bahwa dampak dari manajemen pengelolaan terhadap perkembangan usaha dari minimarket Al-Khaibar adalah hasil dari kinerja manajemen dari minimarket Al- Khaibar yang tumbuh dan terus berkembang begitu pesat. Nadzir yayasan UNISMA mengelola wakaf produktif dengan professional dan amanah karena mampu mendirikan usaha minimarket AlKhaibar dari wakaf uang tunai yaitu dengan modal pendirian usaha dari keuntungan wakaf produktif sebelumnya didirikan yaitu ruang rawat inap VIP di RSI UNISMA.

${ }^{41}$ Achmad Zawawi Mochtar, Ketua Nadzir, Wawancara, (Malang, 9 Januari 2020) 


\section{PENUTUP}

Minimarket Al-Khaibar adalah bentuk pengembangan cash waqf linked social entrepreneur yang dikelola oleh nadzir dari ruang rawat inap kelas VIP di Rumah Sakit UNISMA Malang. Manajemen pengelolaan wakaf produktif yang digunakan sesuai dengan teori George R Terry yaitu planning, organizing, actuating dan controlling. Manajemen pengelolaan dan pengembangan wakaf produktif yang sukses dengan bukti minimarket pertama bernama Al-Khaibar berlokasi di Jalan Tata Surya Malang, minimarket kedua terletak di sebelah Masjid Rois Dahlan Malang, minimarket ketiga terletak di Masjid Sabilillah Malang, minimarket keempat bekerja sama dengan Pondok Pesantren Pondok Al-Kharomain yang berlokasi di Pujon Malang, minimarket kelima bekerja sama dengan investor AT Mart yang berlokasi di Jalan Bondowoso Malang, dan minimarket terakhir bekerja sama dengan komunitas investor Koperasi BB Mart yang berlokasi di Jalan Bantaran Malang. Alokasi manfaat dari hasil bisnis telah tepat sasaran dari semua minimarket, laba dialokasikan 60\%-70\% untuk pengembangan wakaf, 20\%-30\% mauquf'alaih dan 10\% nadzir.

\section{DAFTAR PUSTAKA}

Abdullah, Muhammad Abid. Hukum Wakaf. Jakarta: Dompet Dhuafa Republika, 2004.

Achsan Djauhari, Manajer, Wawancara, (Malang, o9 Januari 2020).

Achmad Zawawi Mochtar. Ketua Nadzir. Wawancara. (Malang, 9 Januari 2020).

Badan Pusat Statistik Kota Malang. (2019). Profil Kemiskinan di Kota Malang Tahun 2019

https://malangkota.bps.go.id/pressrelease/2020/o1/02/212/profil-

dalam

kemiskinan-kota-malang--maret-2019.html, diakses pada 28 Desember 2019.

Bahron. Guru Madin Masjid Besar Rois Dahlan sebagai mauquf 'alaih. Wawancara. (Malang, 9 Januari 2020).

Barry (Al), Partanto dan Dahlan. Kamus Ilmiah Populer. Yogyakarta: Arkol, 1994.

Chaudhry, Muhammad Syarif. Sistem Ekonomi Islam: Prinsip Dasar. Jakarta: Kencana, 2016.

Chusnul Faizah. Sekretaris Administrasi. Wawancara. (Malang, 9 Januari 2020).

Djunaidi, Achmad Thobieb Al Asyhar. Menuju Era Wakaf Produktif. Depok: Mumtaz Publishing, 2007.

Departemen Agama RI. Al-Quran Special for Muslimah. Jakarta: Cordoba, 2016.

Direktorat Pemberdayaan Wakaf, Direktorat Jendral Bimbingan Masyarakat Islam. Strategi Pengembangan Wakaf Tunai di Indonesia, Jakarta: Departemen RI, 2007.

Fahmi, Nurfaqih, Muhammad Isnan dan Rizqi Anfanni. Social Entrepreneur (Kewirausahaan Sosial) dalam Perspektif Ekonomi Islam. Working Paper Keuangan Publik Islam. No. 8, Seri 1, (2018).

Kahf, Munzir. Al-Waqf Al-Islāmy: Tatawwuruhu, Idāratuhu, Wa Tanmiyyatuhu. Beirūt: Dār al Fikr, 2005. 
Lubis, Suhrawardi K. Wakaf \& Pemberdayaan Umat. Jakarta: Sinar Grafika, 2010.

Mahfud, Sahl. Nuansa Fiqh Sosial. Yogyakarta: LKiS, 2004.

Maskuri Bakri. Imam Masjid Besar Rois Dahlan sebagai mauquf 'alaih. Wawancara. (Malang, 9 Januari 2020)

Muhammad Muhdlor. Team Leader. Wawancara. (Malang, o9 Januari 2020).

Muslim, Imam Abi al Husain Muslim bin al-Hujjaj. Al-Jami’ al-Shahih alMushamma Shahih Muslim. Juz 3. Semarang: Toha Putra, 2004.

Muzarie, Mukhlisin. Hukum Perwakafan dan Implikasinya Terhadap kesejahteraan Masyarakat (Impelementasi Wakaf di Pondok Modern Darussalam Gontor). Jakarta: Kementerian Agama RI, 2010.

Sholihah , Ellen Kurnia Sari dan Fatmah Fatmah, "Pengaruh Potensi, Persepsi, Preferensi dan Perilaku Masyarakat Muslim Surabaya Terhadap Wakaf Uang dengan Sikap sebagai Variabel Intervening” dalam eL-Qist: Journal of Islamic Economics and Business (JIEB) Vol. 7 No. 1 (2017)

Soekanto, Soerjono. Pengantar Penelitian Hukum. Jakarta: UI Press, 1986.

Soenggono, Bambang. Metodologi Penelitian Hukum. Jakarta: PT RajaGrafindo Persada, 1997.

Sofia, Irma Paramita. Model Kewirausahaan Sosial (Social Entrepreneurship) SebagaiGagasan Inovasi Sosial Bagi Pembangunan Perekonomian. Jurnal Universitas Pembangunan Jaya. Vol. 2, No. 1, (2015).

Soni A, Hery Wibowo dan Nulhaqim. Kewirausahaan Sosial: Merevolusi Pola Pikir dan Menginisiasi Mitra Pembangunan Kontemporer. Bandung: UNPAD Press, 2015.

Sudirman. Total Quality Management TQM untuk Wakaf. Malang: UIN Maliki Press, 2013.

Sukarna. Dasar-dasar Manajemen. Bandung: CV. Mandar Maju, 2011.

Terry, George R. Prinsip-prinsip Manajemen. Jakarta: Bumi Aksara, 1993.

Usman, Rachmadi. Hukum Perwakafan di Indnesia. Jakarta: Sinar Grafika, 2013.

Wildana, Manzilati, Muhammad Dandy Alif, Asfi. Hablum minallāh dan Hablumminannās dari Zakah. Jurnal Ilmiah Mahasiswa FEB Universitas Brawijaya. Vol. 2 No. 2, 47, (2013).

Zuhaili (al), Wahbah. Fiqh Islam Wa Adillatuhu. Jakarta: Gema Insani, 2011. 